\title{
"Liguei o rádio pra conferir se era verdade": a credibilidade do radiojornalismo local em tempos de fake news
}

\author{
Rafael Medeiros \\ Universidade Federal de Santa Maria, Programa de Pós-Graduação em Comunicação, Santa Maria, RS, \\ Brasil \\ https://orcid.org/0000-0002-0327-3982
}

\section{Nair Prata}

Universidade Federal de Ouro Preto, Programa de Pós-Graduação em Comunicação, Mariana, MG, Brasil https://orcid.org/0000-0002-9127-7720

\section{Resumo}

As emissoras locais de rádio têm suas programações jornalísticas ancoradas em informações relevantes para o cotidiano da comunidade, contribuindo para a proximidade simbólica com o ouvinte. A credibilidade de um meio de comunicação depende de convenções pré-estabelecidas com sua audiência em contratos de leitura consensuais. Dessa forma, a proposta do artigo é evidenciar os lugares de credibilidade do radiojornalismo local em tempos de diminuição da confiança na imprensa e da difusão de fake news. A pesquisa de recepção, que originou este recorte, tem base multimetodológica e combina aplicação de questionários e realização de entrevistas de história oral e semiestruturadas para analisar os discursos de ouvintes da Rádio Itatiaia Ouro Preto sobre suas experiências de escuta, relação com a cidade de Ouro Preto (MG) e percepções sobre o processo de migração da rádio para FM. Utilizando Análise Textual Discursiva, as entrevistas são exploradas aqui à luz da noção de credibilidade do rádio local. Os resultados apontam que o radiojornalismo local segue como a principal e mais confiável fonte de informação para populações de pequenas cidades.

\section{Palavras-chave}

Radiojornalismo; Rádio local; Credibilidade jornalística; Ouro Preto; Pesquisa de recepção; Fake news. 


\section{Introdução}

A ideia de uma crise de credibilidade jornalística, debatida há anos por pesquisadores e pela indústria midiática, ganhou nova atenção a partir da expansão de tecnologias que possibilitam outras formas de circulação e produção de mídia menos concentrada nos meios hegemônicos ${ }^{1}$. Em um cenário de uso crescente da internet, foram expandidas a criação e difusão de informações para além de um sistema perito jornalístico. Em 2006, Jenkins já atribuía à convergência midiática a possibilidade de transformar os consumidores em produtores de conteúdos de mídia (JENKINS, 2006), fenômeno que vem se amplificando nos últimos anos. Se por um lado essa potencialidade colaborou para suprir as necessidades de reconhecimento (HONNETH, 2009; COULDRY, 2012) de grupos comumente ignorados ou sub-representados pela mídia hegemônica, por outro provocou uma avidez pela instantaneidade informacional e permitiu a difusão em massa de notícias falsas que circulam principalmente por redes sociais digitais e aplicativos de mensagens, colocando em suspeição as informações transmitidas nas esferas online e até mesmo aquelas advindas de meios convencionais.

Diante da crescente polarização política, o descrédito dado a determinadas notícias e fontes de informação tradicionais tornou-se dispositivo retórico para sujeitos ou grupos reafirmarem suas crenças e posicionamentos político-sociais. Quaisquer informações veiculadas pela imprensa que possam atestar entendimento contrário às hipóteses e convicções iniciais dessas pessoas são por elas qualificadas como "fake news". Como define Christofoletti (2018, p. 62), "Fake news não são apenas notícias falsas, mas também plantadas, cultivadas e hipertrofiadas para que desorientem, confundam, enganem.".

A criação de bolhas sociais, unindo pessoas com valores e opiniões semelhantes, o preenchimento do anseio pela informação instantânea, a fragmentação das notícias no meio digital e uma concepção equivocada da internet como "terra sem lei", pelo pouco controle, fazem das plataformas digitais terrenos férteis para a circulação das fake news "[...] espalhadas por indivíduos desavisados ou interessados e por sistemas automatizados, como bots e algoritmos." (CHRISTOFOLETTI, 2018, p. 62). Além disso, as informações efetivamente inventadas ou premeditadamente manipuladas são tecidas em um padrão textual assemelhado à escrita noticiosa, principalmente quando há intenção política na sua

\footnotetext{
1 Não é intenção corroborar para a já conhecida falácia da horizontalidade midiática. Os meios hegemônicos continuam dominando a cadeia de mídia, mas grupos ignorados por esses canais estão amplificando suas vozes por meio de diferentes canais (como podcasts e redes sociais digitais).
} 
produção e no seu uso, estimulando a desconfiança em relação aos meios e conteúdos midiáticos em geral. Dessa forma, por mais que circulem precipuamente nos ambientes digitais das redes sociais, a mídia tradicional também é afetada pelos respingos das notícias falsas, amplificando a desconfiança da população nos meios de comunicação.

0 rádio local foi tomado como fenômeno de estudo neste artigo justamente pelo seu aparente poder de resistência a essa crise de credibilidade jornalística, mantendo-se como a principal e mais confiável fonte de informação entre a população que recorre a ele para confirmar ou não os boatos que circulam antes mesmo das notícias em pequenas cidades.

Este artigo é um desdobramento de pesquisa de recepção ampla realizada em 2018 e 2019 envolvendo ouvintes da Rádio Itatiaia Ouro Preto, uma emissora local da cidade mineira de Ouro Preto², com o objetivo de identificar possíveis mudanças nas experiências de escuta e produção de sentidos a partir do processo de migração ${ }^{3}$ da emissora para FM (MEDEIROS, 2019). Com base multimetodológica - a partir da combinação de: aplicação de questionários, entrevistas com ouvintes e com gestores da rádio, e, Análise Textual Discursiva - o estudo verificou a estruturação do local social da escuta radiofônica, pensando que os ouvintes estão inseridos em núcleos variegados e em tangentes socioculturais que moldam suas memórias e percepções da realidade cotidiana.

0 recorte feito aqui se volta para os lugares de confiabilidade do radiojornalismo local evidenciados nas entrevistas realizadas com uma amostra voluntária de ouvintes, além de respostas registradas em questionário aplicado na primeira fase da investigação. 0 tópico inicial deste artigo apresenta discussão teórica sobre a credibilidade (rádio) jornalística e a dinâmica das crises de confiança na imprensa.

\section{Radiojornalismo e crises de credibilidade}

O desenvolvimento tecnológico, sobretudo da internet, modificou as rotinas de produção, os modos de circulação e as experiências de escuta radiofônica. Como Del Bianco (2011, p. 107) argumenta, o radiojornalismo brasileiro passou por períodos de adequações que incluíram "[...] um processo de remodelagem de linguagem, formato e processo produtivo influenciado pelas mutações das técnicas de produção e dos valores que incidem

\footnotetext{
2 Ouro Preto se localiza na região central do Estado de Minas Gerais, a 96 quilômetros da capital. A população estimada da cidade, em 2018, era de 74 mil habitantes. (INSTITUTO BRASILEIRO DE GEOGRAFIA E ESTATÍSTICA, 2018).

3 A migração das rádios AM para FM é a mais importante mudança na configuração da radiodifusão brasileira em anos, atingindo mais de $90 \%$ das emissoras do país. Como não é o foco deste artigo, para mais informações sobre o processo e desdobramentos, ver: (MEDEIROS, 2019, 2020; PRATA e DEL BIANCO, 2018; FARIAS, 2020).
} 
sobre a construção da noticiabilidade.". 0 caráter informativo do rádio se configurou desde o começo das transmissões no Brasil, ainda na década de 1920, inicialmente, usando o recurso de seleção e leitura de notícias veiculadas pelos jornais impressos, sistema que "[...] desprezava as vantagens e potencialidades do meio. Ao invés de antecipar a divulgação da notícia, copiava-se o que os outros produziram." (DEL BIANCO, 2011, p. 107). Com o desenvolvimento de diversas tecnologias de informação e comunicação (TICS) ao longo dos anos, os processos foram se modificando, incorporando elementos e características que seriam diferenciais do meio radiofônico, como o imediatismo e os recursos de linguagem próprios. Atualmente, com a possibilidade de uso de espaços multimidiáticos, as narrativas foram complexificadas e o potencial interativo do rádio foi amplificado.

Fazendo referência às mudanças em transcurso na radiodifusão, sobretudo mediadas pelas tecnologias, Prata (2008) em Webradio: novos gêneros, novas formas de interação cunhou o termo radiomorfose ${ }^{4}$, afirmando que o rádio, gradualmente, tem se modificado e se adaptado a um contexto online, onde "[...] ao mesmo tempo insere novos formatos, enquanto reconfigura elementos antigos, numa mistura que transforma o veículo numa grande constelação de signos sonoros, textuais e imagéticos." (PRATA, 2008, p. 61). Lopez concorda que "[...] o contexto da radiomorfose afeta práticas, gestão, formas de transmissão, de difusão e de fruição e a própria definição do formato e do conteúdo radiofônicos." (LOPEZ, 2017, p. 1). Assim, é preciso considerar que o jornalismo de rádio também tem sido atingido por todas essas mudanças de um meio que agora se configura como expandido ${ }^{5}$ e hipermidiático ${ }^{6}$. A despeito de todas as metamorfoses, o jornalismo segue notabilizado como um fator significativo da credibilidade do meio. Por sua vez, a credibilidade parte de uma série de convenções pré-estabelecidas entre audiência e emissora.

Para início da compreensão de como é construída a relação de confiança entre ouvinte e rádio, recorremos aos cinco aspectos determinantes para uma audiência fiel listados por Prata (2000): seriedade, qualidade, credibilidade, interatividade e tradicionalidade. 0 assente desses cinco aspectos na identidade de uma emissora forma uma

\footnotetext{
4 O conceito se desdobra do termo midiamorfose utilizado por Fidler (1997) para explicar que novos meios surgem a partir de transformações e adaptações dos meios antigos.

5 Conceito cunhado por Marcelo Kischinhevsky (2016) para se referir às novas possibilidades de transmissão e recepção do rádio que extrapola as ondas hertzianas e pode ser consumido por meio de diferentes aparelhos, como smartphones, computadores, tablets, televisores, smartspeakers e notebooks.

6 A narrativa do rádio hipermidiático “[...] apresenta-se como multimídia, mas sempre fundamentada em uma base sonora, por isso se configura como rádio. Esta comunicação sonora pretende garantir a eficácia comunicacional e é complementada pelo conteúdo multimídia de transmissão multiplataforma." (LOPEZ, 2010, p. 9).
} 
rede não simbólica que dialoga com aspectos simbólicos, afetivos e sensoriais, gerando uma percepção de segurança informacional e um sentimento de pertença. É desse modo que, em noção concordante, o pesquisador Mozahir Bruck (2019) trata dos contratos de leitura e de comunicação ${ }^{7}$ para explicar, entre outras questões, a credibilidade adquirida pelos meios:

\begin{abstract}
Dentro da práxis comunicacional, os contratos de leitura, por sua vez, se revelam na credibilidade que determinados veículos alcançam; as concessões que são obrigados a fazer em termos de programação em função de exigências do público, a exigência do estabelecimento de uma identidade estética e explicitação das maneiras de abordagem das coisas do mundo. A busca pela identificação e aproximação com o receptor é uma das maneiras pelas quais os media renovam permanentemente seus contratos. (BRUCK, 2019, p. 431).
\end{abstract}

Especificamente sobre o rádio, Kischinhevsky (2016, p. 134) analisa que a forma de relação estabelecida entre a audiência e o meio faz com as emissoras tenham que "escutar permanentemente seus públicos". Os ouvintes podem apontar o que querem ouvir, contribuir com informações, reverberar notícias e interagir de maneira mais próxima com os comunicadores, "[...] forçando o rádio a ser melhor, a prestar serviços de utilidade pública, a informar correta e eticamente, a apresentar a diversidade social e cultural, sem representar clichês e estereótipos." (KISCHINHEVSKY, 2016, p. 134).

Tendo em vista as assertivas de que a comunicação é uma forma organizativa e política na sociedade contemporânea (SODRÉ, 2014) e de que as conformações sociais passam por constantes modificações que redefinem modos cotidianos de vida, inclusive experiências e formas de consumo midiático, os contratos de leitura revelados na credibilidade dos media precisam acompanhar essas mudanças socioculturais de modo a manter os acordos afetivos-intelectivos com a audiência. A percepção da população em geral com relação às notícias e ao jornalismo está sendo alterada, ressoando alguns efeitos do acesso ampliado às redes sociais digitais, da busca por outros campos de informação e até mesmo uma perda de qualidade nos conteúdos noticiosos, sendo este último um dos reflexos da precarização do trabalho jornalístico.

Como Pena (2005) pondera, a crença de que a mídia reflete a realidade como um espelho serve para dar "[...] legitimidade e credibilidade aos jornalistas, tratando-os como

\footnotetext{
7 De acordo com Bruck, os contratos de comunicação e leitura podem ser percebidos “[...] como um acordo afetivo-intelectivo que os media e públicos estabelecem entre si. Os contratos revelam a opção do receptor não apenas por um modo de se mostrar o mundo, mas denotam definições a partir de identificações e representações que se estabelecem a partir do político e do ideológico, da ética e a moral, o estético e o psicológico." (BRUCK, 2019, p. 431).
} 
imparciais, limitados por procedimentos profissionais e dotados de um saber de narração baseado em método científico que garante o relato objetivo dos fatos." (PENA, 2005, p. 126). Os avanços das TICs possibilitaram novas formas de interação e organização social mediada em torno de ideias comuns ao passo que

[...] jornais, revistas, emissoras de rádio e televisão vão paulatinamente se afastando do público e não conseguem, por mais que tentem, romper com a comunicação unidirecional e monopolizada que consolidaram ao longo dos anos sem dar muito valor àqueles que fazem parte do público, ou da audiência, tomados muito mais como números a serem contabilizados na comercialização de anúncios. (SOMMA NETO, 2018, n. p.).

Portanto, essa crença de "espelho do real" que legitimaria a atividade jornalística e concederia credibilidade às notícias tem perdido espaço para a instantaneidade das informações compartilhadas entre grupos com interesses semelhantes nos espaços de redes sociais digitais.

Pesquisa realizada pela Cision com dois mil jornalistas de dez países, incluindo o Brasil, apontou que 63\% dos participantes sentiram perda de confiança da audiência em relação à mídia em 2019, número inferior aos aferidos pela pesquisa nos dois anos anteriores (CISION, 2019). Entretanto, outro levantamento realizado em 2018 no Brasil pelo Instituto Reuters, da Universidade de Oxford, mostrou que 59\% das duas mil e sete pessoas participantes confiam nas notícias veiculadas pelos meios de comunicação. O Instituto Reuters indicou ainda forte crescimento no acesso e difusão de informações por meio de smartphones nos últimos cinco anos, impulsionado pelo uso de aplicativos de mensagens como o WhatsApp. 0 aplicativo mostrou-se um terreno fértil para a circulação de notícias, já que $48 \%$ da população pesquisada acessa conteúdo noticioso via WhatsApp e $61 \%$ desses usuários afirmaram compartilhar a informação recebida (CARRO, 2018).

A instantaneidade na circulação de informações proporcionada pelo aplicativo trouxe questionamentos nas eleições presidenciais brasileiras de 2018, quando o WhatsApp foi usado para o compartilhamento em massa de conteúdos falsos ou enganosos. Estudo da Universidade Federal de Minas Gerais (UFMG), em conjunto com outras universidades, analisou as imagens políticas mais compartilhadas durante o processo eleitoral e constatou que apenas 8\% delas eram totalmente verdadeiras (VALENTE, 2018). Com isso, as temáticas relacionadas ao falseamento de informações tornaram-se assuntos recorrentes no cotidiano 
noticioso brasileiro e o termo fake news, que em 2017 já havia sido eleita a palavra do ano por um dicionário britânico ${ }^{8}$, passou a ser um problema também na democracia brasileira.

Müller e Souza (2018, p. 2) afirmam que “[...] 'notícias falsas', 'mentiras', 'boatos', 'fatos alternativos', entre outros, têm sido utilizados como sinônimos ou equivalentes à 'fake news'.". Contudo, Gelfert (2018, p. 95, tradução nossa9 ${ }^{\text {) }}$ esclarece que qualquer definição de fake news "[...] deve estar situada em relação a essas variadas formas de desinformação pública e às distorções do processo comunicativo.". Assim, o significado do termo em literal tradução deveria ser expandido contextualmente, "[...] especialmente à luz do fato de que ele já foi cooptado para propósitos políticos contraditórios [...]” (GELFERT, 2018, p. 95, tradução nossa ${ }^{10}$ ). No entanto, todas essas formas que o termo fake news apresenta têm desdobramentos teóricos e, nesse sentido, outras possibilidades de interpretação. 0 boato, por exemplo, tem gênesis e desdobramentos sociológicos que ultrapassam a ancoragem da definição de notícia falsa, mas se apresenta como:

[...] o mais antigo dos meios de comunicação de massa. Antes mesmo de existir a escrita, o ouvi-dizer era o único veículo de comunicação nas sociedades. O boato veiculava as informações, fazia e desfazia as reputações, precipitava os motins ou as guerras. Apesar dos mídias, o público continua a buscar informações através do ouvi-dizer. A emergência dos mídias, longe de suprimir o boato, contribuiu para torná-lo mais especializado: a partir desse momento cada mídia tem seu próprio território de comunicação. (KAPFERER, 1993, p. 4).

Em cidades pequenas, os boatos circulam antes mesmo das notícias de rádio e o "ouvi-dizer" muitas vezes serve para pautar a imprensa local. Enquanto a credibilidade das mídias tradicionais tem sido colocada à prova, os meios de comunicação local aparecem como ilhas em meio a essa crise amplificada pelas fake news. Uma ouvinte entrevistada no âmbito deste trabalho sintetiza a discussão traçada até aqui e ajuda a comprovar essa evidência da credibilidade que o rádio local continua tendo com sua audiência fiel:

Às vezes, a gente ouve alguém falar alguma coisa que não tem muita certeza e liga o rádio que daqui a pouco a gente fica sabendo [...]. A gente

\footnotetext{
${ }^{8}$ Desde 2013, o dicionário Collins indica um verbete que integrará sua próxima edição. A equipe que organiza a seleção afirmou que em 2017 as menções a fake news aumentaram 365\%. Fake news "[...] foi um termo amplamente usado por Donald Trump quando estava em campanha para a presidência, em geral para se referir a notícias negativas sobre ele [...]" (BBC, 2017).

${ }^{9}$ No original: "Any putative definition of 'fake news' must be situated in relation to these varied forms of public disinformation and distortions of the communicative process." (GELFERT, 2018, p. 95).

${ }^{10}$ No original: "[...] especially in light of the fact that it has, by now, been co-opted for contradictory political purposes [...]" (GELFERT, 2018, p. 95).
} 
ouve muito boato. Esses dias mesmo alguém me falou que caiu um barranco ali em cima perto do Veloso ${ }^{11}$ e eu fui e liguei o rádio pra conferir se era verdade. (ENTREVISTADA 6, 2018, grifo nosso).

As dinâmicas do rádio local são exploradas a seguir e mais adiante serão evidenciados os lugares de credibilidade do radiojornalismo local que fazem com que ouvintes continuem ligando o rádio para conferir a veracidade ou não de um boato.

\section{0 rádio local}

As emissoras locais têm raízes consistentes no ambiente onde estão inseridas. Seja por meio da linguagem, identificação dos ouvintes com os locutores, assuntos abordados, sotaques e expressões próprias da comunidade, essas rádios buscam reverberar a rotina e as manifestações sociais locais. A mídia ajuda a conformar ou modificar modos identitários, uma vez que "O consumo cultural midiático participa da organização da cotidianidade e da conformação da competência cultural." (RONSINI, 2007, p. 70). Quando concebe os valores sociais do lugar em que está inserida, a rádio local gera formas comunicacionais que são partilhadas com a população, retratando a realidade com base nos diferentes componentes de construção social. Assim, ao investigar o rádio no contexto local, é fundamental associar suas diferentes dinâmicas, que convergem no campo comunicacional, buscando em alguma medida as representações cotidianas que constroem as características das sociabilidades do local ligadas "[...] aos ethos, valores, significados contidos de coisas, palavras, gestos, comportamentos e ideias." (PESAVENTO, 2006, p. 36).

As dinâmicas de proximidade no rádio local são, então, alinhavadas por componentes sociais e identitários. Peruzzo (2005, p. 78) esclarece que “[...] a mídia de proximidade caracteriza-se por vínculos de pertença, enraizados na vivência e refletidos num compromisso com o lugar e com a informação de qualidade[...]". Ao reconhecer as singularidades locais e associar sua linguagem com as especificidades cotidianas da população, a rádio cria vínculos que facilitam o estabelecimento dos contratos de leitura, dos acordos afetivo-intelectivos, e que vão além da associação dialógica emissora-ouvinte. "Sendo assim, o meio de comunicação local tem, teoricamente, a possibilidade de mostrar, melhor que qualquer outro, a vida em determinadas regiões, municípios, cidades, vilas, bairros, zonas rurais, comunidades, etc." (SANTOS, 2010, p. 52). Cebrián Herreros (2001)

${ }^{11}$ Região próxima ao centro de Ouro Preto. 
concorda que, além de constituir um elemento de identificação com a comunidade onde está inserida, a rádio local efetivamente atende aos interesses e às necessidades da população, estando "[...] centrada na vida social, econômica, política e cultural de sua área de abrangência e também em tudo o que ocorre em seu exterior e que tenha repercussões na vida da comunidade." (CEBRIÁN HERREROS, 2001, p. 146, tradução nossa12).

A inserção física da rádio em meio à sua audiência pode facilitar o interesse do ouvinte, a credibilidade da emissora e as possibilidades interativas, além de aumentar o sentimento de pertencimento. $\mathrm{Na}$ medida em que o imaginário coletivo concebe a importância da comunicação no seu cotidiano, a existência de uma emissora próxima gera esse sentimento de pertença ao reverberar acontecimentos finítimos ao ouvinte, que se vê representado e percebe o rádio como elemento da vida diária, estabelecendo laços de confiabilidade. As conexões estabelecidas entre comunicação, cotidianidade, manutenção de identidades e representações são evidenciadas por Martín-Barbero:

A comunicação é percebida, em todo caso, como o cenário cotidiano do reconhecimento social, da constituição e expressão dos imaginários a partir dos quais as pessoas representam aquilo que temem ou que têm direito de esperar, seus medos e suas esperanças. (MARTíN-BARBERO, 2003, p. 63).

Para a população local, os meios de comunicação, em especial o rádio, assumem papel importante na constituição de subjetividades, dialogismos e relações sociais. Como evidencia Kischinhevsky, "O rádio é o meio de comunicação eletrônica mais local jamais desenvolvido, mesmo tendo hoje alcance planetário." (KISCHINHEVSKY, 2016, p. 134). Além de prestar serviços de utilidade pública, informando sobre acontecimentos que afetam diretamente a localidade, em muitas cidades do interior ele serve como elo de comunicação entre pessoas da sede do município e habitantes da zona rural. 0 rádio é o único meio de comunicação que consegue chegar em diversas regiões afastadas dos centros urbanos.

Embora o radiojornalismo local se paute sobremaneira em ocorrências relacionadas aos poderes oficiais da cidade e acontecimentos regionais, as emissoras locais têm se aberto “[...] a conteúdos mais característicos dos meios comunitários de comunicação, justamente numa fase da história em que o clamor pela cidadania tomou conta de vários segmentos, pessoas individualmente e instituições da sociedade civil." (PERUZZO, 2005, p. 75). 0 rádio

\footnotetext{
12 No original: "Se centra en la vida social, económica, política y cultural de cada lugar o bien en todo cuanto se genera en el exterior con repercusiones en la vida de la localidad." (CEBRIÁN HERREROS, 2001, p. 146).
} 
potencializou suas dinâmicas de proximidade e interação, até mesmo emissoras locais perceberam a necessidade de ocupar espaços na internet como forma de facilitar a comunicação com o ouvinte e manter a audiência ${ }^{13}$. Ainda assim, a dimensão geoespacial do rádio é fator importante para definição de características básicas de uma emissora, como linguagem e formato, e também, para a manutenção da confiabilidade.

Esta pesquisa foi desenvolvida com ouvintes da Rádio Itatiaia Ouro Preto e, em muitos momentos, a emissora é citada nos depoimentos que serão explorados adiante, portanto, é preciso apresentar a rádio para uma melhor compreensão do artigo.

A história da Rádio Itatiaia Ouro Preto teve início oficialmente em 27 de abril de 1974, quando a emissora começou a funcionar com o nome de Rádio Cultura de Ouro Preto, sendo a primeira rádio legalizada da cidade (MARINHO, 1982, p. 2). De acordo com uma das primeiras funcionárias da emissora, Nazaré de Oliveira (2018), a programação pioneira da Rádio Cultura de Ouro Preto foi configurada a partir de notícias locais e música popular brasileira. 0 jornalismo da Rádio Ouro Preto, já nessa época, era baseado em informações locais e prestação de serviços. O primeiro programador da emissora, Maurílio Torres, salienta que "[...] as notícias eram mais de Ouro Preto [porque] era obrigatório na programação das rádios ter notícias locais." (TORRES, 2018) e Nazaré Oliveira relembra que "[...] a equipe fazia coberturas da semana santa, do vinte e um de abril, sete de setembro e de qualquer outra solenidade que tinha." (OLIVEIRA, 2018).

Como evidência da tradicionalidade da rádio e da proximidade com seus ouvintes com base na comunidade local, a população ainda se refere à emissora apenas pelo nome da cidade: "Rádio Ouro Preto". Marcadamente constituída com características de emissora local, a rádio segue como o principal e mais duradouro meio de comunicação da cidade dos inconfidentes, reverberando acontecimentos da vida diária da população ouro-pretana, inserindo-se no cotidiano da cidade e confirmando um lugar de afeto e confiabilidade entre os habitantes.

\section{Apontamentos metodológicos}

A pesquisa de recepção originária deste recorte foi realizada a partir de uma matriz multimetodológica explorando os discursos dos ouvintes da Rádio Itatiaia Ouro Preto a

\footnotetext{
${ }^{13}$ Em pesquisa nacional sobre a migração do rádio AM para FM, realizada com emissoras do interior, Prata e Del Bianco (2018) mostram que mais de $90 \%$ das rádios pesquisadas possuem site na internet e cerca $85 \%$ das emissoras têm página no Facebook e usam o WhatsApp como meio de comunicação com o ouvinte.
} 
respeito das suas experiências de escuta, uso de dispositivos, percepções sobre a emissora e sobre o processo de migração da rádio para FM. Nos idos iniciais da pesquisa, uma busca documental constatou a existência de parcos dados que pudessem colaborar para o entendimento da constituição da Rádio Itatiaia Ouro Preto. Diante da impossibilidade de se obter dados com base em arquivos, a entrevista de história oral foi o método encontrado para a recuperação de dados históricos da emissora. As entrevistas foram feitas com três pessoas que contribuíram de diretamente para a efetivação da rádio: a primeira secretária, o primeiro programador e um importante incentivador da rádio nos seus anos iniciais.

O convite para participação voluntária dos ouvintes foi feito por meio de spots veiculados na rádio e de anúncios em jornais locais impressos de ampla circulação contendo o endereço eletrônico para um questionário com questões sobre o comportamento da audiência, suas experiências de escuta, uso de dispositivos receptores de rádio, percepções gerais sobre a emissora e sobre o processo de migração. Com o objetivo de aprofundar os dados obtidos, substanciar as informações e pormenorizar questões específicas, foram realizadas entrevistas semiestruturadas com sete dos 47 ouvintes respondentes do questionário. A tabela que se segue apresenta alguns dados iniciais dos ouvintes entrevistados que ajudam a compreender de forma adequada suas falas sobre a credibilidade da rádio local ouro-pretana no próximo tópico.

Quadro 1 - Identificação dos ouvintes entrevistados ${ }^{14}$

\begin{tabular}{|l|l|l|l|}
\hline \multicolumn{1}{|c|}{ Identificação } & \multicolumn{1}{c|}{ Gênero } & Idade & \multicolumn{1}{c|}{ Ocupação } \\
\hline Entrevistada 1 & Feminino & 27 & Jornalista \\
\hline Entrevistada 2 & Feminino & 53 & Professora \\
\hline Entrevistado 3 & Masculino & 52 & Pedreiro \\
\hline Entrevistada 4 & Feminino & 46 & Agente legislativo \\
\hline Entrevistado 5 & Masculino & 53 & Pedreiro \\
\hline Entrevistada 6 & Feminino & 78 & Costureira \\
\hline Entrevistada 7 & Feminino & 52 & Costureira \\
\hline
\end{tabular}

Fonte: Elaborado pelos autores com dados da pesquisa.

${ }^{14}$ Para resguardar a identidade das pessoas entrevistadas, elas serão identificadas conforme a primeira coluna do quadro. 
As questões definidas para as entrevistas partiram da observação dos dados do questionário, mas não se limitaram a eles. A base qualitativa da pesquisa toma, desse modo, as entrevistas como elementos centrais da investigação, mas não despreza nenhuma outra unidade de sentido gerada anteriormente nessa matriz multimetodológica pensada para a pesquisa. 0 método da Análise Textual Discursiva (ATD) é usado para a análise qualitativa dos dados buscando o entendimento das complexas mediações presentes na temática abordada aqui.

A Análise Textual Discursiva pode ser entendida como o processo de desconstrução, seguido de reconstrução, de um conjunto de materiais linguísticos e discursivos, produzindo-se, a partir disso, novos entendimentos sobre os fenômenos e discursos investigados. (MORAES; GALIAZZI, 2016, p. 134).

Os discursos que interessam neste artigo são os que se conectam à noção de credibilidade do rádio local.

\section{Análise: lugares de credibilidade no radiojornalismo local}

Em meio à crise da credibilidade da imprensa, a rádio local consegue manter a confiabilidade do seu ouvinte por meio de diferentes contratos de leitura. Um desses acordos simbólicos bilaterais é a função primeira dessas emissoras: informar sobre o que é importante para o ouvinte, para o cotidiano da cidade, mesmo que sejam notas de falecimento ou campanhas de vacinação. Quem define o que é importante nesse caso é o ouvinte.

Embora se volte para notícias locais, incluindo os distritos ouro-pretanos, a Rádio Itatiaia Ouro Preto também veicula informações de outras cidades em alguns momentos da programação, mas não com a mesma frequência e profundidade dos acontecimentos locais. Uma entrevistada diz gostar desse formato de programação noticiosa: “[...] eu gosto do que ela faz: ela dá a notícia daqui direitinho e depois vai passando de hora em hora notícia de Minas, do mundo." (ENTREVISTADA 7, 2019).

Se $59 \%$ da população brasileira ouvida na pesquisa do Instituto Reuters disse confiar nas notícias veiculadas pela mídia em geral (CARRO, 2018), 80,1\% dos ouvintes da Rádio Itatiaia Ouro Preto ouvidos na presente investigação afirmaram que a emissora tem credibilidade para veicular as notícias da cidade, sendo considerado fator importante para que essas pessoas continuem ouvindo a rádio, conforme aponta o gráfico a seguir: 
Gráfico 1 - Escala de importância do quesito credibilidade para os ouvintes da Rádio Itatiaia Ouro Preto

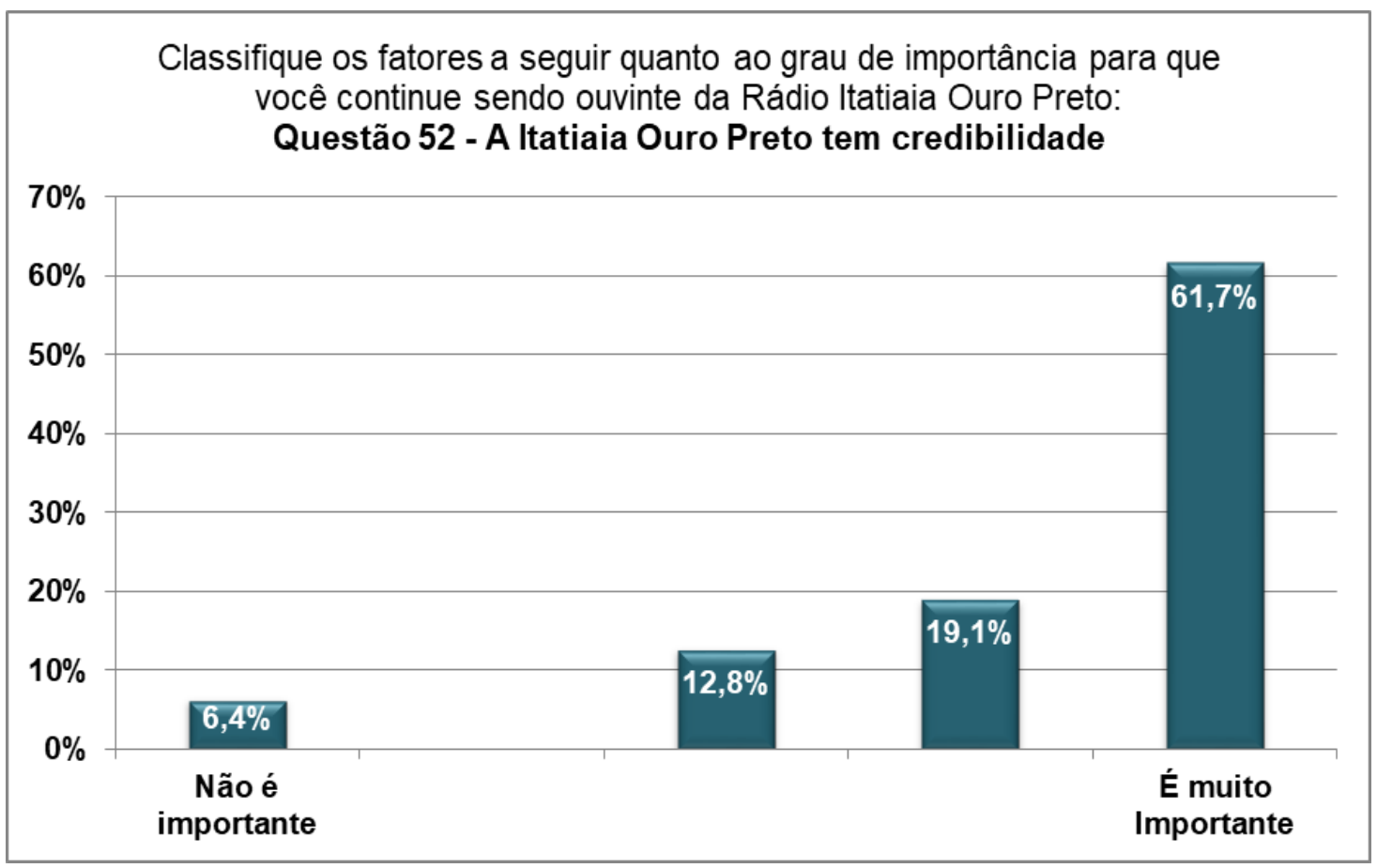

Fonte: Elaborado pelos autores com dados da pesquisa.

Para o entrevistado 3, a localização é argumento importante para a confiabilidade na exatidão das notícias veiculadas pela Rádio Itatiaia Ouro Preto:

A notícia tá aqui, eles também, então a notícia chega na hora. Pra gente que é da cidade, quando ouve a notícia na Rádio Ouro Preto, recebe muito melhor porque quando a rádio daqui fala você sabe de que ponto da cidade está falando, já uma rádio de fora não localiza tão bem. (ENTREVISTADO 3, 2019).

Ao atestar a confiança nas notícias veiculadas pela Rádio Itatiaia Ouro Preto, uma ouvinte entrevistada se refere às fontes jornalísticas para justificar que a emissora local tem mais capacidade de transmitir fielmente as informações da cidade que emissoras de outras regiões porque ela "[...] sabe até quem vai poder falar e dar a notícia certa." (ENTREVISTADA 2, 2019). Sobre essa questão, Lopez (2009) afirma que

[...] as fontes podem ser classificadas conforme sua aproximação geográfica, sendo locais, nacionais ou internacionais. Desta forma é possível mostrar ao ouvinte como esses eventos afetam seu cotidiano e assim atender a um dos princípios fundamentais desse meio de comunicação. 0 que diferencia mais essas fontes é o acesso a elas. Fontes locais podem ser consultadas de maneira direta, através de contato pessoal 
do jornalista, da sua presença no palco de ação, ou ainda através de contato telefônico. (LOPEZ, 2009, p. 108).

No radiojornalismo local as principais fontes tendem a ser autoridades da cidade e órgãos oficiais que são vistos como mais confiáveis pela população. A confiabilidade adquirida pela emissora vem, em grande medida, da qualidade das notícias e da profundidade da apuração. A proximidade também contribui para a qualidade das informações veiculadas “[...] por causa desse índice alto de audiência. O pessoal escuta muito, então se ela [a rádio] errou, logo todo mundo fala na hora que tá errado." (ENTREVISTADA 1, 2019).

É nesse sentido que $78,7 \%$ dos ouvintes que responderam ao questionário consideram que as notícias transmitidas pela Rádio Itatiaia Ouro Preto são verídicas e que esse é um quesito importante para que eles continuem ouvindo a rádio após a migração para FM, como mostra o gráfico seguinte:

Gráfico 2 - Escala de importância do quesito veracidade para os ouvintes da Rádio Itatiaia Ouro Preto

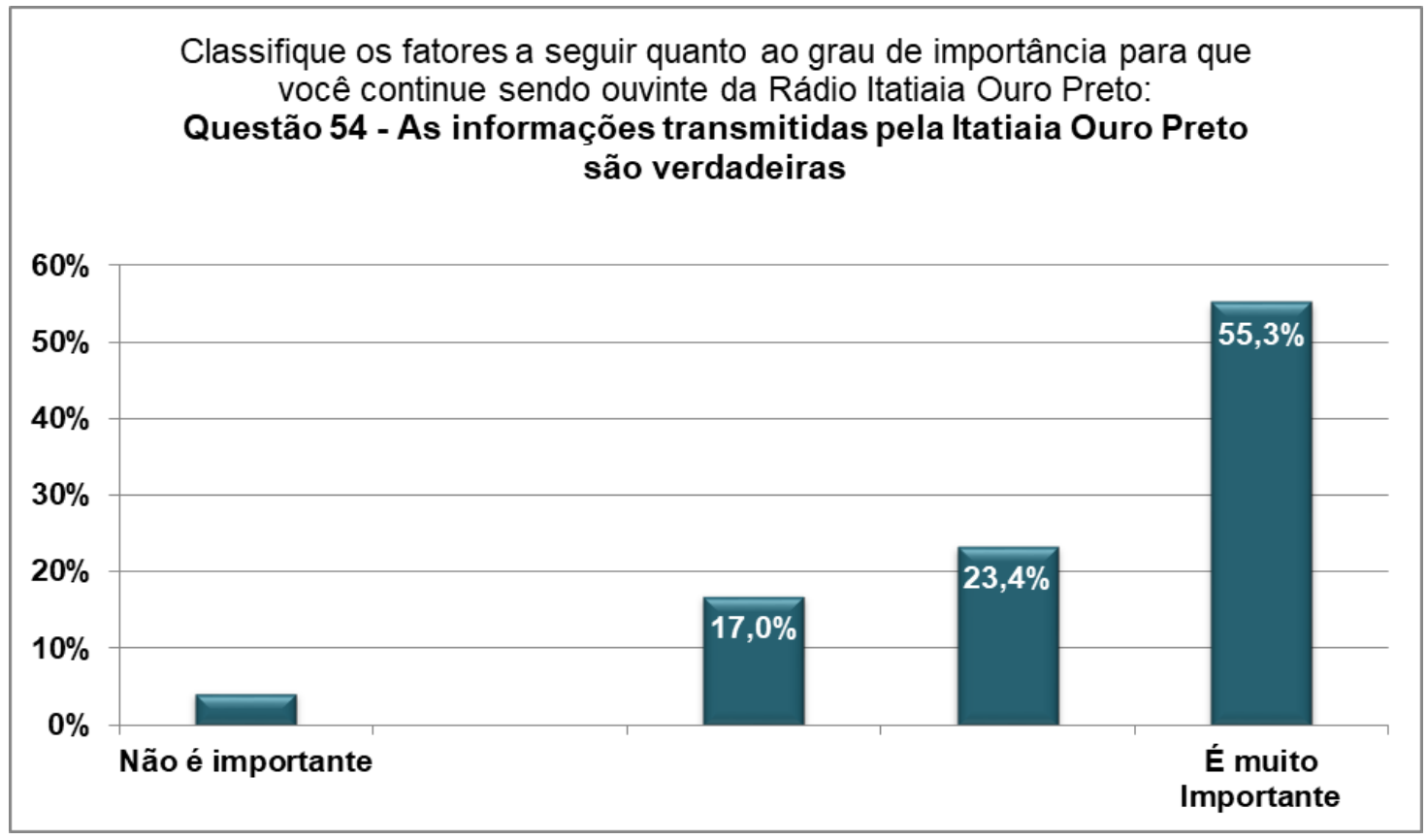

Fonte: Elaborado pelos autores com dados da pesquisa.

Ao ser questionado sobre suas principais fontes de informação, o entrevistado 5 é direto ao afirmar que "[...] é o rádio. É a Rádio Ouro Preto. Não tem jeito de não falar que não é. Se quer ficar bem-informado sobre sua cidade não dá pra ouvir rádio de BH, 
Inconfidência ${ }^{15}$ igual a gente ouvia antes de ter a Rádio Ouro Preto." (ENTREVISTADO 5, 2019). A relação que os ouvintes desenvolvem com os apresentadores é outro aspecto que se interliga com a proximidade entre ouvinte e rádio e que pode ser evidenciado como característica importante nos lugares de credibilidade do radiojornalismo local. Ferraretto explica que

[...] o comunicador acompanha donas de casa, idosos, motoristas de táxi, operários..., quebrando a solidão do dia a dia com uma programação marcada por doses de assistencialismo, entretenimento, fofocas a respeito de artistas, horóscopo, noticiário policial, serviço e canções de apelo fácil. E faz a intermediação na tentativa de resolver problemas: do transporte deficiente na periferia à localização de algum parente perdido na vertiginosidade da vida contemporânea. (FERRARETTO, 2014, p. 75).

Nas rádios locais, a sensação de familiaridade é amplificada porque o comunicador geralmente é uma figura conhecida da população. A quarta ouvinte entrevistada evoca a importância dos apresentadores nessa formação da relação de confiabilidade entre rádio e ouvinte: "Dos locutores da Itatiaia, de Ouro Preto, a gente ouve falar nas roças, agora dessas outras rádios a gente não ouve falar." (ENTREVISTADA 4, 2019). Ao ser questionada sobre a permanência dos locutores nos mesmos programas por muitos anos, a entrevistada que escuta a rádio há mais tempo não titubeia ao responder que

[...] eles ficam como se fossem pessoas da gente, sabe? Você fala em Antônio Carlos ${ }^{16}$ como se estivesse falando de um filho. Outro dia eu tava no Siame ${ }^{17}$, aprendendo a fazer uns negócio lá e ele apareceu, eu falei com ele: "Ó, minhas panelas já queimaram muitas vezes por sua culpa". E ele falou: "Uai, por quê?". "Uai, porque você fica falando, eu fico escutando, quando vou ver a comida já queimou". Aí ele começou a rir. E quantas vezes, muitas vezes, eu já deixei a panela queimar porque tava escutando ele falar? Chega lá o arroz já era... (ENTREVISTADA 6, 2019).

Assim, o comunicador tem papel fundamental na criação dos contratos de leitura e nas formas de interação do ouvinte com a emissora porque, ao usar linguagem aproximada da população na interlocução, ele "[...] vai oferecendo emoções e reações emuladas com a voz em um diálogo imaginário marcado por um caráter informal." (FERRARETTO, 2014, p.

\footnotetext{
15 Localizada em Belo Horizonte, a Rádio Inconfidência é uma das emissoras mais antigas Minas Gerais, em funcionamento desde 1936. Durante muitos anos transmitiu eventos religiosos na cidade de Ouro Preto. (PRATA, 2010; MEDEIROS, 2019).

${ }^{16}$ Antônio Carlos é o apresentador do programa mais longevo da Rádio Itatiaia Ouro Preto, no ar há mais de 30 anos.

17 O Serviço Interprofissional de Atendimento à Mulher (Siame) foi criado em 1996 na cidade de Ouro Preto para apoiar mulheres vítimas de violência. Hoje, além da assistência prestada a essas mulheres, oferece diversas oficinas de artesanato também para pessoas não atendidas pelo instituto.
} 
76) e criando um laço de confiança com a audiência. Essa informalidade e a proximidade (também física) com as pessoas da cidade faz com que elas se sintam parte da emissora, já que os comunicadores, e a rádio como um todo, fazem parte do dia a dia delas.

É importante considerar que a Rádio Itatiaia Ouro Preto presta também um papel assistencialista típico das rádios locais do interior e, mais uma vez, a confiança que a população tem nos comunicadores se coloca à mostra, como exemplifica uma entrevistada: "Hoje na programação da manhã toda ele [Antônio Carlos] tava pedindo uma cama hospitalar pra uma pessoa que tá doente na Bauxita ${ }^{18}$. Pede cama, pede remédio, pede tudo e num instantinho ele consegue [...]" (ENTREVISTADA 6, 2018). Todos os entrevistados afirmaram já ter colaborado com alguma pessoa ou instituição por solicitação da rádio. 0 caráter comportamental do jornalismo interiorano sobressai à sua estrutura e se estabelece "[...] com a política da vizinhança, a solidariedade, o coletivismo, os valores, a moral, a fé religiosa, o respeito humano e a cultura de pequenas populações, sobressaindo-se, por exemplo, o bairrismo e a solidariedade entre os moradores." (DORNELLES, 2004, p. 3).

A rede de relações cotidianas de um lugar é produzida a partir de variantes entrelaçadas, sejam afetivas, memoriais, políticas, culturais, históricas ou territoriais. 0 rádio nesse tocante tem a capacidade de se voltar para seu lugar originário e reforçar esses elementos. Todos os entrevistados afirmam reconhecer que a realidade local é um conceito ligado à cidade onde eles vivem, reforçando que o entendimento de lugar enquanto território geográfico não pode ser descolado daquele que o concebe enquanto território de disputa e de construção de sociabilidades. López García reforça que:

[...] o local evoca aquilo que se pode ver, tocar, aprender e, portanto, ser compreendido. Sem dúvida, é a partir dos espaços locais que se definem os contornos da vida diária, onde se constrói a personalidade social e onde se faz a aprendizagem social. Nesse cenário de proximidade, privilegiado para a diversidade e a particularidade, é onde o social, o cultural e o político parecem reencontrar-se prioritariamente. (LÓPEZ GARCÍA, 1999, p. 247, tradução nossa $\left.{ }^{19}\right)$.

O local nesse sentido evoca a vida cotidiana da população e a rádio tem capacidade de demarcar aspectos do dia a dia e reforçar costumes construídos socialmente. Essa

\footnotetext{
${ }^{18}$ Bairro de Ouro Preto.

${ }^{19}$ No original: "Deste xeito, podemos dicir que o local, tamén neste escenario que facilita a globalización, segue evocando aquelo que se pode ver, tocar, aprender e, polo tanto, ser compreendido. Sen dúbida, desde os espacios locais é desde onde se definen os retos da vida diaria, onde se constrúe a personalidade social e onde se fai aprendizaxe social. Neste escenario de proximidade, privilexiado para a diversidade e a particularidade, é onde o social, o cultural e o político parecen reencontrase de xeito prioritário." (LÓPEZ GARCÍA, 1999, p. 247).
} 
característica ainda aproxima a emissora dos ouvintes que a veem como uma força importante dentro do estrato social e político da cidade, seja como prestadora de serviços ou até mesmo como agente de poder capaz de pressionar as instâncias governamentais para a resolução de problemas cotidianos:

\begin{abstract}
Hoje mesmo uma mulher ligou da Bocaina, um lugar pequenininho aqui perto de Cachoeira ${ }^{20}$ (minha filha mora lá), falando que estão sem sinal de telefone. Ele pôs ela direto no ar e falou que ia cobrar pra ela. Eu falo que essa rádio ajuda muito. Minha água ficou vazando aqui, eu liguei umas cinquenta vezes pra prefeitura e não resolveu, eu liguei uma vez pra rádio, ele falou lá e no outro dia eles vieram. Eu sempre falo que se tá pedindo alguma coisa na prefeitura e não faz, liga pro Antônio Carlos que é só ele falar que o negócio resolve. (ENTREVISTADA 6, 2018).
\end{abstract}

Os demais entrevistados também identificam na rádio uma forma de saber sobre acontecimentos muito próximos que influenciariam diretamente em seus cotidianos. O lugar social da escuta é compartilhado e os temas expostos na Rádio Itatiaia Ouro Preto se transformam em assuntos da vida diária e ganham lugar nas conversas entre vizinhos, amigos, familiares e, mais recentemente, na arena ampliada das redes sociais online.

As notícias chegam aos ouvintes pelo aparelho tradicional usado há mais de 20 anos pela entrevistada mais velha, pelo celular usado pela ouvinte mais nova ou ainda pelo receptor do carro de um dos ouvintes que agora consegue sintonizar a rádio em FM. 0 rádio ajuda a organizar a vida diária do entrevistado que acorda para trabalhar ao som do rádio relógio e da entrevistada que só vai fazer o almoço depois que seu programa favorito termina. A experiência de escuta é coletiva no caso da agente legislativo que ouve a Rádio Itatiaia Ouro Preto junto a colegas de trabalho, já para a professora que passa a manhã sozinha em casa, a escuta é individual e, assim, o rádio persiste com uma de suas funções primárias, a de companheiro.

\title{
6 Considerações finais
}

As pesquisas de recepção radiofônica representam uma parcela pequena dentro dos estudos sobre rádio e as abordagens dos trabalhos com foco no ouvinte comumente fazem "[...] um levantamento da audiência de forma abstrata, transformando-a em números.", sem articular o processo de comunicação de maneira mais ampla (CORUJA; JACKS, 2017, p. 88-

${ }^{20}$ Bocaina é uma comunidade rural de Ouro Preto e "Cachoeira" se refere à Cocheira do Campo, distrito do município. 
89). Além disso, os processos de recepção não podem ser desvinculados do "[...] contexto complexo e multidimensional em que as pessoas vivem o seu cotidiano." (VASSALLO DE LOPES, 2000, p. 98). Tendo em vista essa realidade múltipla e intricada que precisa estar no radar dos estudos de recepção, os depoimentos dos ouvintes da Rádio Itatiaia Ouro Preto explorados como corpus da investigação que gerou este texto foram delimitados também no entendimento da conjuntura local e anfêmera da cidade patrimônio ${ }^{21}$, dos hábitos e das experiências de escuta e de suas relações estruturais, históricas e de aproximação com o lugar, nas articulações múltiplas entre práticas e processos cotidianos.

Por meio da pesquisa de recepção que envolveu 47 ouvintes da mais antiga rádio ouro-pretana, foi possível verificar que os lugares da credibilidade da emissora estão ancorados nas interseções e derivações da sua tradicionalidade e da proximidade com a audiência. A proximidade, por sua vez, é estabelecida e mantida por contratos de leitura e comunicação simbólicos e impermanentes que são acordados entre emissora e ouvinte. Esses contratos denotam e sugestionam configurações da emissora que são alicerçadas nas escolhas do ouvinte, com base em múltiplos veios sociais conexos de identificações e representações que vão do estético ao político, do afetivo ao intelectivo. Desse modo, foi primordial no estudo entender o que é determinante para a credibilidade do rádio local a partir do viés do ouvinte.

Ao passo em que o desenvolvimento de novas tecnologias dilui algumas fronteiras, a comunicação mediada por meios digitais designa um novo lugar às dinâmicas de proximidade e, com a possibilidade de acesso rápido a múltiplos conteúdos midiáticos, a conformação da mídia local na sociedade conectada em rede ganha ainda mais importância: muitas vezes, só ela mostra as realidades da cidade. Desde 1974, a Rádio Itatiaia Ouro Preto desempenha esse papel na antiga capital de Minas Gerais, sendo parte do cotidiano da cidade, advertindo a respeito de problemas no abastecimento de água, alteração no recolhimento do lixo, veiculando notas de falecimento, informando a respeito do clima e sobre tudo o que a audiência julgar como importante. Dessa forma, o entendimento de local como lugar geográfico se acerca da compreensão simbólica de lugar como construto de relações sociais, trocas afetivas, reconhecimento intersubjetivo e valores culturais compartilhados.

\footnotetext{
210 epíteto faz referência ao reconhecimento da cidade de Ouro Preto como patrimônio da humanidade sendo a primeira propriedade cultural do Brasil tombada pela UNESCO, em 5 de setembro de 1980, por seu valor histórico e arquitetônico.
} 
Em pesquisa sobre os fatores determinantes de uma audiência fiel, Nair Prata (2000) já apontava a tradicionalidade como um dos pilares para que os ouvintes continuassem escolhendo uma mesma emissora de rádio. É importante destacar que a tradicionalidade de uma rádio não envolve apenas o período em atividade, mas também a manutenção da programação, do formato e da linha editorial e, preponderantemente para a emissoras locais, a permanência dos locutores. Para $68,1 \%$ dos ouvintes que responderam ao questionário, a emissora ser tradicional é fator muito importante na escolha pela Rádio Itatiaia Ouro Preto, indicador que é complementado pelos depoimentos analisados neste artigo.

Enquanto a credibilidade da imprensa vem sendo questionada no atual cenário marcado pela instantaneidade informacional, disseminação de fake news e ofuscamento da noção de verdade, fatores que contribuem para uma percepção falseada da realidade, o rádio local segue mantendo a confiança dos ouvintes, renovando os contratos de leitura e comunicação com a audiência. Isso evidencia que um dos caminhos para a mídia enfrentar as crises de credibilidade seria reforçar os elementos de proximidade com sua audiência.

\section{Referências}

BBC. 'Fake News' é eleita palavra do ano e ganhará menção em dicionário britânico. São Paulo: BBC News Brasil, 2 nov. 2017. Disponível em: https://bbc.in/2Mpl1BM. Acesso em: 27 jun. 2021.

BRUCK, Mozahir. Jornalismo em reconfiguração: notas sobre contratos e contratações. Brazilian Journalism Research, Brasília, v. 15, n. 2, p. 418-437, ago. 2019.

CARRO, Rodrigo. Brazil. In: NEWMAN et al. Digital news report 2018. Oxford: Reuters Institute for the Study of Journalism, 2018.

CEBRIÁN HERREROS, Mariano. La radio en la convergencia multimedia. Barcelona: Gedisa, 2001.

CHRISTOFOLETTI, Rogério. Padrões de manipulação no jornalismo brasileiro: fake news e a crítica de Perseu Abramo 30 anos depois. Revista Rumores, São Paulo, n. 23, v. 12, jan./jun., 2018.

CISION. Distrust in the media is decreasing. In: Cision's 2019 Global State of the Media Report, Chicago: Cision Ltd., n. 10, 2019. p. 1-23.

COULDRY, Nick. Media, society, world: social theory and digital media practice. Cambridge: Polity Press, 2012 
CORUJA, Paula; JACKS, Nilda. Rádio e audiências: processos e práticas em transformação. In: JACKS, Nilda; et al. (orgs.). Meios e audiências III: reconfigurações dos estudos de recepção e consumo midiático no Brasil. Porto Alegre: Sulina, 2017.

DEL BIANCO, Nélia. As transformações técnicas na produção do radiojornalismo e os valores-notícias: jornalismo de rádio: referencial histórico. In: MOREIRA, Sonia Virgínia (Org.). 70 Anos de Radiojornalismo no Brasil 1941-2011. Rio de Janeiro: EdUERJ, 2011.

DORNELLES, Beatriz. Jornalismo comunitário em cidades do interior: uma radiografia das empresas jornalísticas: administração, comercialização, edição e opinião dos leitores. Porto Alegre: Sagra Luzzato, 2004.

FARIAS, Karina Woel de. Do AM para o FM: adaptações do radiojornalismo na migração de dial em Santa Catarina. 2020. Tese (Doutorado em Jornalismo) - Programa de PósGraduação em Jornalismo, Universidade Federal de Santa Catarina, Florianópolis, 2020.

FERRARETTO, Luiz Artur. Da segmentação à convergência: apontamentos a respeito do papel do comunicador de rádio. Comunicação \& Sociedade, São Bernardo do Campo, v. 36, n. 1, 2014, p. 59-84.

FIDLER, Roger. Mediamorphosis: understanding new media. Califórnia: Pine Forge Press, 1997.

GELFERT, Alex. Fake News: a definition. Informal Logic, Windsor, v. 38, n. 1, 2018. p. 84117.

HONNETH, Axel. Luta por reconhecimento: a gramática moral dos conflitos sociais. 2. ed. São Paulo: Editora 34, 2009.

INSTITUTO BRASILEIRO DE GEOGRAFIA E ESTATÍSTICA. Pesquisa Nacional por Amostra de Domicílios: síntese de indicadores. Rio de Janeiro: IBGE, 2010.

JENKINS, Henry. Convergence culture: where old and new media collide. New York: New York University Press, 2006.

KAPFERER, Jean-Noël. Boatos: o mais antigo mídia do mundo. Trad. Ivone S. R. Maya. Rio de Janeiro: Forense Universitária, 1993.

KISCHINHEVSKY, Marcelo. Rádio e mídias sociais: mediações e interações radiofônicas em plataformas digitais de comunicação. Rio de Janeiro: Mauad X, 2016.

LOPEZ, Debora Cristina. Radiojornalismo hipermidiático: tendências e perspectivas do jornalismo de rádio all news brasileiro em um contexto de convergência tecnológica. 2009. Tese (Doutorado em Comunicação) - Programa de Pós-Graduação em Comunicação e Cultura Contemporâneas, Universidade Federal da Bahia, Salvador, 2009.

LOPEZ, Debora Cristina. Radiojornalismo hipermidiático: tendências e perspectivas do jornalismo de rádio all news brasileiro em um contexto de convergência tecnológica. Covilhã: Livros LabCom, 2010. 
LOPEZ, Debora Cristina. La radio en narratives immersives: le contenu journalistique et l'audience. Trad. Debora Cristina Lopez. In: POULAIN, Sebastien (org.). La radio du futur: du téléchromophotophonotétroscope aux postradiomorphoses. Cahiers d'histoire de la radiodiffusion, v. 1, n. 132. Paris: Comité d'histoire de la radiodiffusion. avril/juin, 2017.

LÓPEZ GARCIA, Xosé. Medios locais do futuro e con futuro. In: ANDIÓN, Margarida; KUNSCH, Margarida (orgs.). Comunicación audiovisual: investigación e formación universitarias. Santiago de Compostela: Universidade, Servicio de Publicacións e Intercambio Científico, 1999. p. 245-254.

MARINHO, Vânia. Maior orgulho de José Russo é ser ouro-pretano honorário. Jornal de Ouro Preto, Ouro Preto, 19 dez. 1982.

MARTÍN-BARBERO, Jesús. Globalização comunicacional e transformação cultural. In: MORAES, Denis de (Org.). Por uma outra comunicação: mídia, mundialização cultural e poder. Rio de Janeiro: Record, 2003. p. 71-94.

MEDEIROS, Rafael. 0 rádio e a cidade patrimônio: experiências de escuta, localismo e migração nos discursos de ouvintes Ouro-Pretanos. 2019. Dissertação (Mestrado em Comunicação) - Programa de Pós-Graduação em Comunicação, Universidade Federal de Ouro Preto, Mariana, 2019.

MEDEIROS, Rafael. A função social do rádio local entre desertos de notícias e zonas de silêncio: reverberações da migração AM-FM. Revista Latino-americana de Jornalismo Âncora, João Pessoa, v. 7, n. 1, p. 360-378, 2020.

MORAES, Roque; GALIAZZI, Maria do Carmo. Análise textual discursiva. 3. ed. Ijuí: Editora Unijuí, 2016.

MÜLLER, Felipe; SOUZA, Márcio Vieira de. Fake News: Um problema midiático multifacetado. Anais do Congresso Internacional de Conhecimento e Inovação - ciki, $[S$. l.], v. 1, n. 1, set. 2018.

OLIVEIRA, Maria Nazaré. 0 começo da Rádio Ouro Preto. Entrevista cedida a Rafael Medeiros. Ouro Preto, ago. 2018.

PENA, Felipe. Teoria do Jornalismo. São Paulo: Editora Contexto, 2005.

PERUZZO, Cicília. Mídia regional e local: aspectos conceituais e tendências. Comunicação \& Sociedade, São Bernardo do Campo, v. 26, n. 43, 2005.

PESAVENTO, Sandra. Fronteiras culturais em um mundo planetário - paradoxos da(s) identidade(s) sul-latino-americana(s). Revista del CESLA, Warsaw, n. 8, p. 9-19, jan. 2006.

PRATA, Nair. A fidelidade do ouvinte de rádio: um estudo dos principais fatores determinantes da audiência fiel. 2000. Dissertação (Mestrado em Comunicação Social) Programa de Pós-Graduação em Comunicação Social, Universidade São Marcos, São Paulo, 2000. 
PRATA, Nair. Webradio: novos gêneros, novas formas de interação. 2008. Tese (Doutorado em Linguística Aplicada) - Programa de Pós-Graduação em Estudos Linguísticos da Universidade Federal de Minas Gerais, Belo Horizonte, 2008.

PRATA, Nair; DEL BIANCO, Nélia. Impacto da migração do rádio AM para o FM no Brasil. In: PRATA, Nair; DEL BIANCO, Nélia. Migração do rádio AM para o FM: avaliação de impacto e desafios frente à convergência tecnológica. Florianópolis: Insular, 2018. p. 39-62

RONSINI, Veneza. Mercadores de sentido: consumo de mídia em identidades juvenis. Porto Alegre: Sulina, 2007.

SANTOS, Maria Cláudia. A importância do noticiário local de rádio em tempos de globalização: uma análise da opinião dos ouvintes da Rádio Itatiaia. 2010. Dissertação (Mestrado em Gestão Social, Educação e Desenvolvimento Local) - Centro Universitário UNA, Belo Horizonte, 2010.

SOMMA NETO, João. Eleição de Bolsonaro e o fim da credibilidade da mídia jornalística tradicional. ObjETHOS, Florianópolis, 31 out. 2018.

SODRÉ, Muniz. A Ciência do comum: notas sobre o método comunicacional. Petrópolis: Vozes, 2014.

TORRES, Maurílio. A primeira programação da Rádio Ouro Preto. Entrevista cedida a Rafael Medeiros, Ouro Preto, ago. 2018.

VALENTE, Jonas. Pesquisa constata só 8\% de imagens verdadeiras em grupos de WhatsApp. Agência Brasil, Brasília, 17 out. 2018.

VASSALLO DE LOPES, Maria Immacolata. Metodologias para o estudo da recepção de telenovelas no Brasil. Comunicação e Sociedade, Braga, Portugal, v. 2, p. 93-112, 2000.

\title{
"I turned on the radio to see if it was true": the credibility of local broadcast in times of fake news
}

\begin{abstract}
Local radio stations have their journalistic programs anchored in information relevant to the daily life of the community, contributing to the symbolic proximity to the listener. The credibility of a media depends on pre-established conventions with its audience in consensual reading contracts. Thus, the purpose of the article is to highlight the places of credibility of local radio journalism in times of reduced confidence in the press and the spread of fake news. The reception research, which originated this clipping, has a multi-methodological basis and combines the application of questionnaires and oral history and semi-structured interviews to analyze the speeches of Radio Itatiaia Ouro Preto listeners about their listening experiences,
\end{abstract}


relationship with the city of Ouro Preto (MG) and perceptions about the migration process from radio to FM. Using Discursive Textual Analysis, the interviews are explored here in light of the local radio's notion of credibility. The results show that local radio journalism continues to be the main and most reliable source of information for populations in small towns.

\section{Keywords}

Broadcast journalism; Local radio; Journalism credibility; Ouro Preto; Reception studies; Fake news

\section{Autoria para correspondência}

Rafael Medeiros

rfmedeiros13@gmail.com

\section{Como citar}

MEDEIROS, Rafael; PRATA, Nair. "Liguei o rádio pra conferir se era verdade": a credibilidade do radiojornalismo local em tempos de fake news. Intexto, Porto Alegre, n. 52, e-98044, jan./dez. 2021. DOI: http://dx.doi.org/10.19132/1807-8583202152.98044

Recebido em 07/11/2019

Aceito em 20/07/2021 